\title{
Primary Bartholin Adenocarcinoma: a Rare Case and Radiotherapy as Definitive Treatment
}

\author{
Lokot Donna Lubis ${ }^{1}$, Sarah Dina ${ }^{2}$, Derissa Khairina Khaidirman ${ }^{3}$ \\ ${ }^{1}$ Department of Histology, Faculty of Medicine, Universitas Sumatera Utara, Medan, Indonesia \\ ${ }^{2}$ Obstetric and Gynaecologic Department, Haji Adam Malik Hospital, Medan, Indonesia \\ ${ }^{3}$ Royal Prima Hospital, Medan, Indonesia
}

Corresponding author: Lokot Donna Lubis, Department of Histology, Faculty of Medicine, Universitas Sumatera Utara, Medan, Indonesia; E-mail: 2lokdonlub@gmail.com; Tel.: +6287868873737

Received: 15 Aug 2020 Accepted: 21 Oct 2020 Published: 31 Dec 2021

Citation: Lubis LD, Dina S, Khaidirman DK. Primary Bartholin adenocarcinoma: a rare case and radiotherapy as definitive treatment. Folia Med (Plovdiv) 2021;63(6):985-9. doi: 10.3897/folmed.63.e57633.

\begin{abstract}
Primary vulvar adenocarcinoma is a very rare neoplasm, accounting for only $1 \%$ of all gynecologic malignancies. Most of the glandular carcinomas originated from the Bartholin's gland. Because of the rare incidence, the pathogenesis and radiotherapy response are not fully understood. A 47-year-old female from our hospital was diagnosed with primary Bartholin adenocarcinoma and received radiotherapy as definitive treatment. We evaluated the presence of high-risk and low-risk human papillomavirus (HPV) DNA to associate the role of HPV infection, and evaluated its molecular features by the expression of vimentin, p16, estrogen receptor, progesterone receptor, S-100, and Ki 67.
\end{abstract}

\section{Keywords}

Bartholin's gland adenocarcinoma, radiotherapy, vulvar cancer

\section{INTRODUCTION}

Malignant epithelial vulvar neoplasms are relatively uncommon, accounting for about $2 \%-5 \%$ of all gynecologic malignancies ${ }^{1}$ and the adenocarcinoma subtype is even more uncommon, accounting for only $1 \% .^{2}$ Most of the glandular carcinomas arise from Bartholin's glands or from other anogenital glands such as skin adnexal structures, mammarylike glands, the Skene's glands, and Paget disease., ${ }^{2,3}$ Human papillomavirus (HPV) may have a crucial role in the genesis of Bartholin gland carcinomas (BGC), although the exact pathogenesis remains speculative. Different histologic subtypes may have different HPV type infection., ${ }^{4,5}$

The management strategy of vulvar adenocarcinoma is similar to that of squamous cell carcinoma (SCC) and depends principally on the histological subtype and surgical staging. ${ }^{1}$ Radiotherapy or simultaneous chemoradiation has been used as an option for definitive treatment in patients unfit for surgery or as a preoperative treatment prior to surgery in advanced cases to avoid pelvic exenteration procedures. Among women who received primary radiotherapy as definitive treatment, only $17.8 \%$ of the cases finally underwent surgical resection. ${ }^{6}$

We report a primary papillary Bartholin adenocarcinoma in a 47-year-old female in whom we evaluated the molecular phenotype by immunohistochemistry, examined the presence of HPV DNA sequences to link a possible role of HPV infection, and discuss the treatment of this rare tumour.

\section{CASE REPORT}

A 47-year-old female presented to Haji Adam Malik Hospital, Medan, Indonesia with a 1-year history of a protruding mass from her vagina. The mass began as a small painless nodule and started to secrete a mucoid secretion without any history 
of leukorrhea or post-coital bleeding. The genital examination demonstrated a $4 \times 4-\mathrm{cm}$, exophytic, nodular polypoid mass, covering the lower third distal vaginal wall, and the base originated from the right posterolateral of the vagina (Fig. 1A).

No gynecological abnormalities were found on abdominal ultrasonography. A pelvic magnetic resonance imaging revealed a $3 \times 5 \times 10.5-\mathrm{cm}$, solid, and cystic-irregular mass arising from the vagina without any invasion to the cervix and the uterus (Fig. 2). An incisional biopsy was performed. Histopathological review of the biopsy tissue demonstrating a very well differentiated papillary adenocarcinoma morphologically reminiscent of papillary Bartholin carcinoma (Figs 3A, 3B). Normal Bartholin's tissue was not found anywhere.

To exclude another carcinoma invasion to the vulva, immunostaining was used and revealed negative stains for vimentin, p16, estrogen receptor (ER), and progesterone receptor $(P R)$, hence confirming the vulva as the origin of the mass (Fig. 3D). S100 was also used to demonstrate the myoepithelial component but also showed a negative stain. The tumour was a low proliferative carcinoma demonstrated by only $10 \%$ positivity of Ki67 (Fig. 3C). HPV DNA genotyping test used to detect high-risk $(16,18,31,33,35,39,45,51,52$, 53, 56, 58, 59, 66, and 68) and low-risk HPV DNA (6, 11, 42, 43, 44, and 81); however, HPV DNA sequences were not detected. Colonoscopy followed by a rectal biopsy did not find any other local carcinoma.

The clinical presentation, physical findings, and pathological examination were consistent with primary papillary Bartholin adenocarcinoma with a stage T2NOMO according to FIGO classification. We decided that the best management would be a tumour-directed external beam radiation therapy (EBRT) with a total dose of $50.4 \mathrm{~Gy}$ divided into 28 fractions (1.8 Gy fractions) followed by brachytherapy 30 Gy (5 Gy fractions) as a boost. The tumour was responsive to radiation and showed a significant clinical improvement after the 24th fraction (Fig. 1, right). The patient currently has been free from the disease for 10 months post-radiotherapy and has only minor complications such as pain and secondary infection in the perineal area.

\section{DISCUSSION}

Malignant lesions of the vulva are relatively infrequent, accounting for about $4 \%$ of all gynecologic cancers and SCC, and their precursor lesions comprise $95 \%$ of them. ${ }^{2,3}$ BGC is a primary carcinoma of diverse cell types located at the site of the Bartholin's gland and commonly affecting postmenopausal women ${ }^{7}$ but may also occur in the reproductive age groups. ${ }^{8}$ BGC is characteristically solid growth, deeply located, often deeply infiltrative, and difficult to detect in their beginning. ${ }^{9}$ Common presenting features include vulvar pruritus or pain, non-menstrual vaginal bleeding, and discharge ${ }^{8}$, or a slow-growing lump or ulcer or it may be asymptomatic. ${ }^{1}$ In our case, the patient is a 47 -year-old woman with a 12-month history of an exophytic vaginal mass. She ignored the lump until it covered her distal vaginal wall. Financial limitations and lack of access to health care resulted in a delay of care.

HPV DNA has been detected in the BGC of squamous
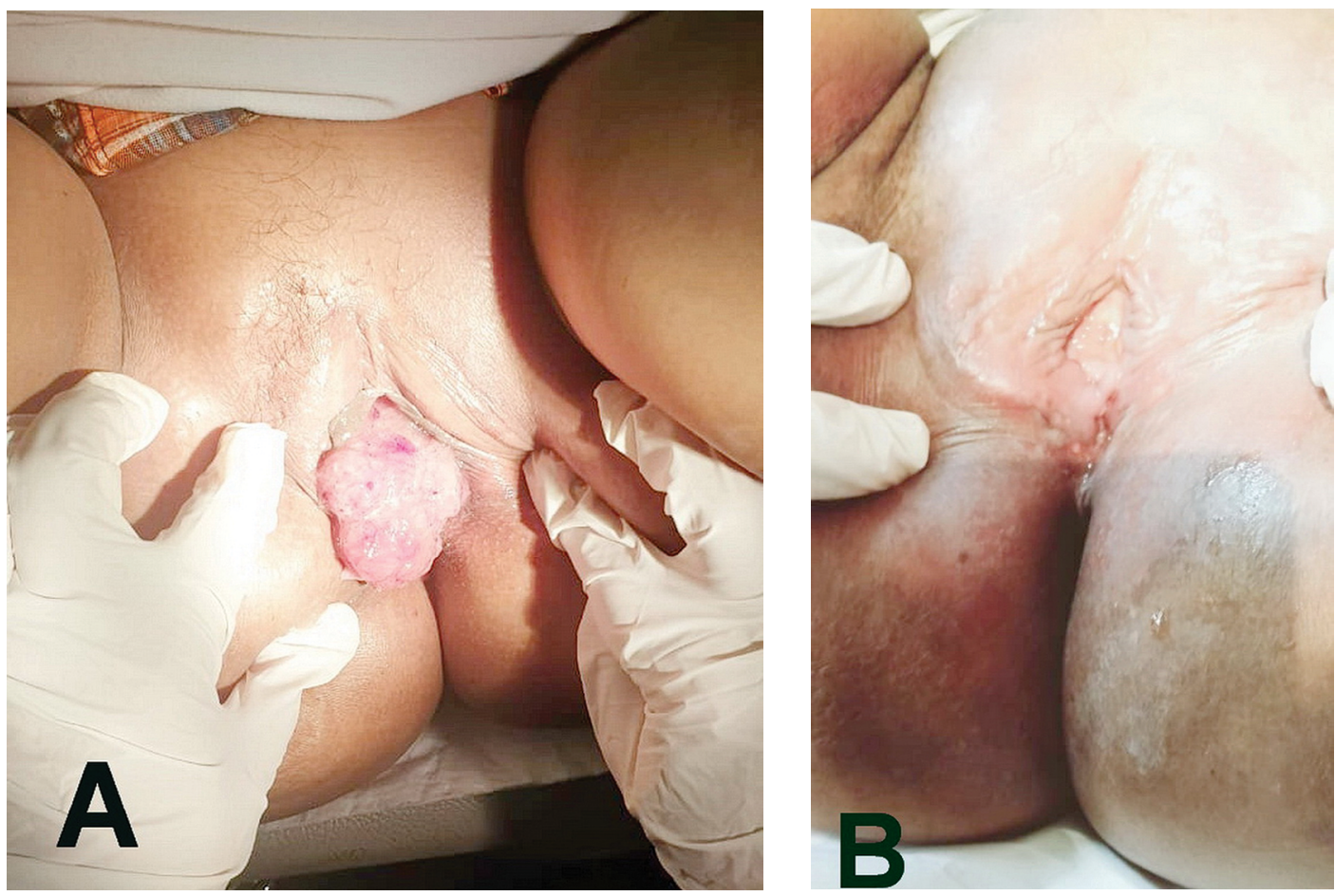

Figure 1. Photograph of the mass, before (A) and after radiotherapy (B). A. A large, exophytic, granulose mass protruding from the vagina, covering half of the distal vaginal wall. The mass dimensions were $4 \times 4 \mathrm{~cm}$; B. Significant clinical improvement of the papillary Bartholin adenocarcinoma after the 20th fraction (1.8 Gy) tumour directed external beam radiation therapy. 

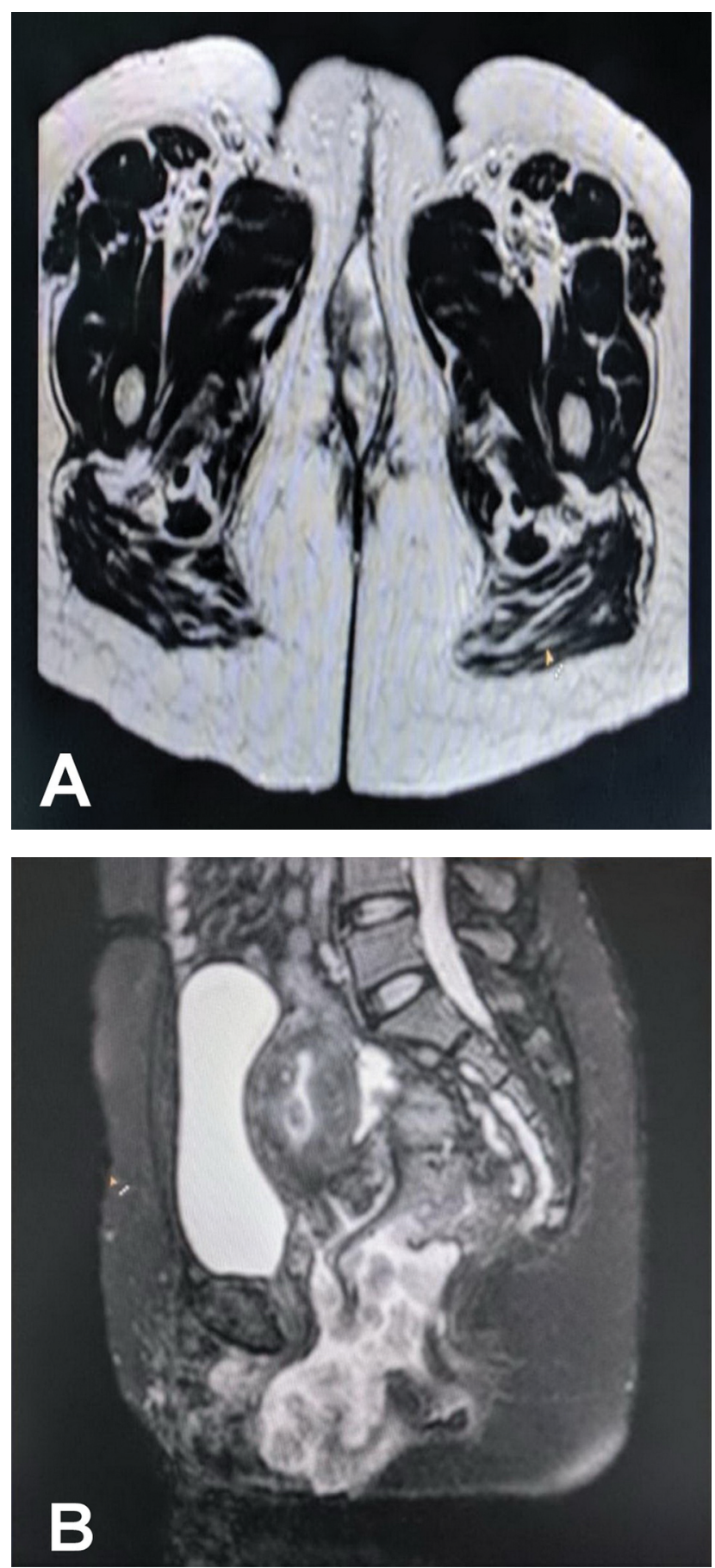

Figure 2. The pelvic MRI image. The pelvic MRI images with contrast revealed a $3 \times 5 \times 10.5 \mathrm{~cm}$, solid, and cystic-irregular mass arising from the vagina without any invasion to the cervix and the uterus.

and transitional type. ${ }^{9}$ Previous case series and case report suggested that HPV may have a critical role in the development of BGC. Felix et al. identified HPV DNA, type 16 in particular, in six out of seven SCC, but not in an adenocarcinoma case. ${ }^{4}$ Ohno et al. also reported HPV DNA 16 and 18 were undetected in mucinous Bartholin's adenocarcinoma. HPV infection involvement was also ruled out in our case as the high-risk and low-risk HPV DNAs were not detected. Yet, it is well known that the sensitivity of PCR methods for HPV DNA detection is lower for formalin-fixed tissues than for fresh tissues. ${ }^{5}$

The histopathologic diagnostic criteria for the BGC described by Chamlian and Taylor's criteria are as follows: 1) transition between the Bartholin's gland and tumour; or 2) the tumour located in the area of Bartholin's gland, is histologically compatible with Bartholin origin, and the tumour must not be metastatic to a Bartholin's gland. ${ }^{8}$ BGC has several histopathologic subtypes including adenocarcinomas (40\%), squamous cell carcinomas (40\%), adeno squamous carcinomas (approximately 5\%), adenoid cystic carcinomas (15\%), and transitional carcinoma (5\%). ${ }^{7,9}$ A variety of histologic types of adenocarcinoma have been described such as mucinous, papillary, and mucoepidermoid carcinoma. ${ }^{7}$

The rarity of BGC is related to limited experience as well as limited information on its molecular characteristic. Felix et al. reported that the Bartholin's gland adenocarcinoma showed detectable levels of hormone receptor expression (ER and PR) but not in the squamous carcinoma type. ${ }^{4}$ The SCC expressed p63, high molecular weight cytokeratin, and CK7 meanwhile adenoid cystic carcinoma variant showed reactivity to CEA, CD117, PASD, and the myoepithelial component expressed S100, SMA, and P63. ${ }^{10}$

We followed Chamlian and Taylor's criteria to verify the tumour as BGC. However, the transition zone between the normal gland and tumour was unrecognizable and the size of the tumour may already obliterate the residual normal gland. To differentiate the origin of the tumour and to evaluate its molecular phenotype, we used immunochemical analysis with vimentin, p16, ER/PR, and S100. All antibodies expressed negative stain. Vimentin, ER/PR, and p16 are widely used to discriminate endometrioid carcinoma and endocervical carcinoma. p16 also known as analogous to p53 and stain robustly serous carcinoma of the gynecologic tract. ${ }^{11} \mathrm{HPV}$ infection predisposing in this carcinoma is also ruled out as the HPV DNA genotyping test did not detect any high-risk and low-risk HPV DNA.

The management approach of vulvar adenocarcinoma is similar to SCC and depends primarily on histological subtype and surgical staging. ${ }^{1}$ The management approaches may be surgery, radiotherapy, chemotherapy, or chemoradiation alone or in combination depending on the tumour stage. ${ }^{7}$ In a large vulvar adenocarcinoma series, the International Federation of Gynecology and Obstetrics (FIGO) stages distribution were $25 \%, 42 \%, 28 \%$, and $5 \%$ for stages I, II, III, and IV, respectively. ${ }^{8}$

Radiotherapy is usually used as adjuvant therapy after initial surgery as part of a primary therapy in large and locally advanced vulvar carcinoma or for secondary treatment/palliation in recurrent/metastatic disease. To maximize tumour control and restrain adjoining tissue damage, the choice of radiation technique and doses are paramount. Doses currently used range from 45-50.4 Gy in 25-28 fractions (1.8 Gy fractions) for adjuvant therapy to 59.4-64.8 Gy in 33-36 total fractions (1.8 Gy fraction) for unresectable disease. ${ }^{12}$ Among women who received primary radio- 

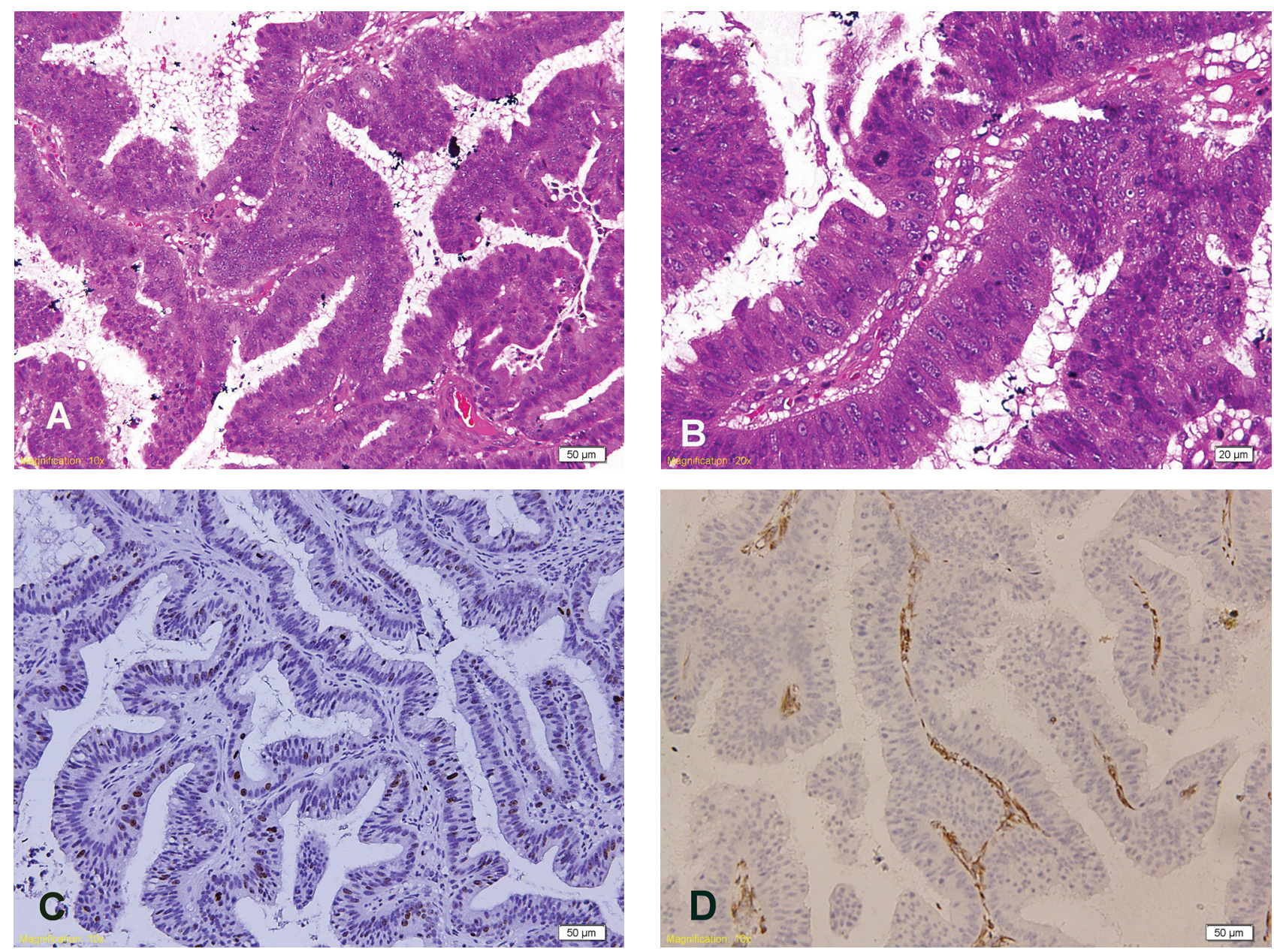

Figure 3. Histopathological review of the biopsy tissue. A. An invasive papillary tumour showing a very well differentiated papillary adenocarcinoma. (Haematoxylin and Eosin, $\times 200$ ); B. The fibrovascular papillae are lined by stratified palisading columnar epithelial cells with moderate nuclear atypicality, and large nucleoli. Nuclear overlap, and crowding with nuclear membrane irregularity. Mitotic activity are 5 in 10 high power field, and atypical mitotic figures are also found. (Haematoxylin and Eosin, $\times 400$ ); C. Low power field of Ki67 immunostaining on the tumour cells, and showed a low-proliferative carcinoma (only 10\% positive stain on the tumour cells). (Ki67 immunostain, $\times 200$ ); D. Immunohistochemical staining of the tumour with vimentin showed anegative staining. (Immunostain Vimentin, $\times 200)$.

therapy as definitive treatment, only $17.8 \%$ of cases finally underwent surgical resection. ${ }^{6}$

In our case, the tumour was treated with EBRT (total dose of $50.4 \mathrm{~Gy}$ ) followed by brachytherapy (total dose of $30 \mathrm{~Gy}$ ), and the response was excellent. The patient currently remains disease-free for 10 months post-radiotherapy.

The 5-year survival rate of this malignancy in one series was $67 \%$ with $54.5 \%$ of patients suffering recurrence during a mean follow-up time of 73.5 months. ${ }^{7}$ In another two series, the 5-year survival rate was approximately $85 \%$ in all histologic subtypes after the patient had complete surgical resection followed by inguinal lymphadenectomy, and in some cases, radiotherapy. Different histologic subtypes may have different outcomes. ${ }^{8}$

\section{CONCLUSIONS}

Bartholin's gland adenocarcinoma is a very rare carcino- ma and only a few cases have been reported. We reported a case of primary Bartholin's gland adenocarcinoma in a 47-year-old female with an excellent response to radiotherapy. Immunohistochemical studies showed a negative stain for vimentin, p16, S100, ER, and PR. There was no link to $\mathrm{HPV}$ infection in the genesis of this tumour.

\section{Funding}

No funding or grant support was obtained.

\section{Conflict of Interest}

Authors have no conflict of interest related to this work.

\section{Disclosure}

Authors have no financial disclosures. 


\section{REFERENCES}

1. Rogers LJ, Cuello MA. Cancer of the vulva. Int J Gynecol Obstet [Internet] 2018; 143:4-13. Available from: https://obgyn.onlinelibrary. wiley.com/doi/epdf/10.1002/ijgo.12609

2. Stueben BL, Lara JF. Primary adnexal adenocarcinoma of the vulva: A diagnosis of exclusion based on location, immunohistochemistry, and pattern of spread. Gynecol Oncol Reports [Internet] 2013; 4:7-8. Available from: http://dx.doi.org/10.1016/j.gynor.2012.11.002

3. Wilkinson EJ. Premalignant and malignant tumors of the vulva. In: Kurman RJ, Ellenson LH, Ronnett BM, editors. Blaustein's Pathology of the Female Genital Tract. 6th ed. New York Dodrecht Heidelberg London: Springer; 2011. p. 87-9.

4. Felix JC, Cote RJ, Kramer EEW, et al. Carcinomas of Bartholin's gland: histogenesis and the etiological role of human papillomavirus. Am J Pathol 1993; 142(3):925-33.

5. Ohno T, Nakano T, Abe A, et al. Mucinous adenocarcinoma of bartholin gland treated with radiation therapy: a case report. Jpn J Clin Oncol 2001; 31(5):226-30.

6. Laliscia C, Gadducci A, Montrone S, et al. Radiotherapy as definitive treatment of patients with primary vulvar carcinoma unfit for surgery and with recurrent vulvar carcinoma after primary radical surgery: results of a retrospective single-center study. Anticancer Res 2016;
36(1):387-91.

7. Crum CP, Herrington CS, McCluggage WG, et al. Epithelial tumours. In: Kurman RJ, Carcangiu ML, Herrington CS, Young RH, editors. WHO classification of tumours of female reproductive organs. 4th ed. IARC Press (Lyon) [Internet]. Lyon; 2014. p. 237-8.

8. Clement PB, Young RH. Atlas of gynecologic surgical pathology. In: Clement PB, Young RH, editors. Atlas of Gynecologic Surgical Pathology. 3rd ed. London: Saunders; 2014. p. 43.

9. Penick E, Beriwal S, Wilkinson EJ, et al. Principles and Practice of Gynecology and Oncology. In: Chi DS, Berchuck A, Dizon DS, Yashar C, editors. Principles and Practice of Gynecology and Oncology. 7th ed. Philadelphia: Wolters Kluwer Health; 2017. p. 409.

10. Nagarajan P, Peters SB. vulvabartholinglandcarc @ www.pathologyoutlines.com [Internet]. PathologyOutlines.com website. 2014 [cited 2020 July 19]. Available from: http://www.pathologyoutlines.com/ topic/vulvabartholinglandcarc.html

11. Rekhtman N, Burkhart A, Duffield A, et al. Quick reference handbook for surgical pathologists. In: Rekhtman N, Bishop JA, editors. Quick Reference Handbook for Surgical Pathologists. Berlin: Springer; 2011. p. 40.

12. National Comprehensive Cancer Network. Vulvar cancer. NCNN Clin Pract Guidel Oncol (NCNN Guidel version 12018 Vulvar cancer. 2017.

\title{
Первичная бартолиновая аденокарцинома: редкий случай и лучевая терапия как окончательное лечение
}

\author{
Локот Дона Лубис ${ }^{1}$, Сара Дина ${ }^{2}$, Дериса Каирина Каидирман ${ }^{3}$ \\ ${ }^{1}$ Кафедра гистологии, Медицинский факультет, Университет Суматера Утара, Медан, Индонезия \\ ${ }^{2}$ Отделение акушерства и гинекологии, Больница „Хаджи Адам Малик“, Медан, Индонезия \\ ${ }^{3}$ Больница Роял Прима, Медан, Индонезия
}

Адрес для корреспонденции: Lokot Donna Lubis, Department of Histology, Faculty of Medicine, Universitas Sumatera Utara, Medan, Indonesia; Е-mail: 2lokdonlub@gmail.com; Тел.: +6287868873737

Дата получения: 15 августа 2020 Дата приемки: 21 октября 2020 Дата публикации: 31 декабря 2021

Образец цитирования: Lubis LD, Dina S, Khaidirman DK. Primary Bartholin adenocarcinoma: a rare case and radiotherapy as definitive treatment. Folia Med (Plovdiv) 2021;63(6):985-9. doi: 10.3897/folmed.63.e57633.

\section{Резюме}

Первичная аденокарцинома вульвы - очень редкое новообразование, составляющее лишь $1 \%$ всех гинекологических злокачественных новообразований. Большинство железистых карцином возникает из бартолиновой железы. Из-за редкой частоты патогенез и ответ на лучевую терапию до конца не изучены. У 47-летней женщины из нашей больницы была диагностирована первичная бартолиновая аденокарцинома, и в качестве окончательного лечения ей была проведена лучевая терапия. Мы оценили наличие ДНК высокого и низкого риска для вируса папилломы человека (ВПЧ), чтобы связать роль инфекции ВПЧ, и оценили его молекулярные свойства, экспрессируя виментин, р16, рецептор эстрогена, S-100 и Кі 67.

\section{Ключевые слова}

аденокарцинома бартолиновой железы, лучевая терапия, рак вульвы 